\title{
ANALISIS POTENSI DAN STRATEGI PENGEMBANGAN PARIWISATA DI KABUPATEN ENDE
}

\author{
Oleh \\ Yustina Paulina Penu \\ Dosen Program Studi Ekonomi Pembangunan \\ e-mail: yustinapenu1201@gmail.com
}

\begin{abstract}
ABSTRAK
Penelitian ini bertujuan untuk menginventarisasikan potensi serta strategi pengembangan pariwisata di Kabupaten Ende sebagai daya tarik wisata, sehingga dapat diambil kebijakan yang dapat digunakan untuk mengembangkan daya tarik ini secara berkelanjutan. Penelitian ini dilakukan di kabupaten Ende. Pengumpulan data pada penelitian ini dilaksanakan dengan menggunakan teknik: 1))Wawancara langsung dengan responden dengan mendatangi responden berdasarkan kuisioner (daftar pertanyaan) yang telah di persiapkan sebelumnya. 2) Observasi, yaitu suatu pengumpulan data dengan pengamatan langsung di lapangan untuk menguji dan melengkapi data lainnya. 3) Dokumentasi yaitu memperoleh data dan informasi yang telah tercatat pada berbagai dokumen tentang berbagai hal yang diperlukan dalam penelitian yang dapat di peroleh pada instansi-instansi terkait, seperti Dinas Pariwisata, TNK, Losmen, Home Stay, Perpustakaan Daerah. Permasalahan dalam penelitian ini dianalisis secara deskriptif kualitatif, analisis IFAS (Internal Factors Analysis Summary) dan EFAS (External Factors Analysis Summary) serta analisis SWOT (Strength Weakneses Opportunities Threat) untuk merancang trategi pengembangannya.

Dari hasil penelitian ditemukan bahwa kondisi internal berupa faktor-faktor kekuatan pada masing-masing Kawasan pariwsata di Kabupaten Ende adalah Panorama alam yang indah, Budaya Masyarakat yang Unik, Peninggalan Sejarah, Kehidupan Sosial Masyarakat yang unik, Hutan yang asri dengan udaranya yang segar. Kondisi internal berupa faktor-faktor kelemahan, diantaranya: kurang tersedianya sarana dan prasarana penunjang aktivitas pariwisata, kurangnya promosi tentang potensi-potensi pariwisata di masing-masing kawasan, kurang teresedianya sumber daya manusia di bidang pariwisata, kurangnya aksesbilitas transportasi udara, laut dan udara serta jalan menuju potensi-potensi wisata masih sempit, kurangnya keterlibatan masyarakat lokal dalam kegiatan pariwisata di tempat mereka. Hasil analisis matriks IFAS didapati bahwa kondisi internal potensi pariwisata di kabupaten Ende berada pada posisi sedang, yaitu dengan total skor 2.33. Kondisi eksternal berupa faktor-faktor peluang pada masing-masing Kawasan meliputi: Adanya misi kabupaten Ende 2014-2019, dekatnya jarak potensi wisata pada kawasan selain kelimutu dengan daya tarik wisata Taman Nasional Kelimutu, letaknya strategis dan berada pada jalur Tengah Kabupaten Ende dan Pulau Flores, adanya kemajuan teknologi informasi dan transportasi, adanya kecenderungan pariwisata dunia menuju pariwisata alami (Back to Nature), Tumbuhnya ekonomi Global. Kondisi eksternal berupa faktor-faktor ancaman adalah ancaman global warming, beredarnya Narkoba, HIV, ancaman pertambahan penduduk akibat migran sehingga terjadi pengalihan fungsi lahan, Perubahan Budaya (komodifikasi) dan Pencemaran lingkungan berupa sampah. Hasil analisis matriks EFAS menunjukan posisi lingkungan eksternal Potensi pariwisata Kabupaten Ende sebagai daya tarik wisata berada pada posisi sedang, yaitu dengan total skor 2.44
\end{abstract}


Strategi umum yang dipakai dalam mengembangkan potensi wisata pada masing-masing kawasan adalah strategi pertahankan dan pelihara. Posisi ini menyatakan bahwa potensi wisata pada masing-masing kawasan pariwisata memiliki posisi daya tarik sedang dan kompetitif rata-rata. Strategi alternatif pengembangan potensi pariwisata, meliputi: strategi pengembangan produk wisata pada masing-masing kawasan, strategi pengembangan sarana dan prasarana, strategi pemasaran produk wisata, strategi pengembangan kelembagaan dan peningkatan SDM di bidang pariwisata, dan strategi pengembangan pariwisata berkelanjutan.

Kata Kunci: potensi, strategi pengembangan pariwisata, kabupaten Ende

\section{ABSTRACT}

This research aims to make an inventory of the potential and strategies for developing tourism in Ende Regency as a tourist attraction, so that policies can be used to develop this attraction in a sustainable manner. This research was conducted in Ende district. Data collection in this study was carried out using the following techniques: 1)) Direct interviews with respondents by visiting respondents based on a questionnaire (list of questions) that had been prepared previously. 2) Observation, which is a collection of data by direct observation in the field to test and complete other data. 3) Documentation, namely obtaining data and information that has been recorded in various documents about various things needed in research that can be obtained from related agencies, such as the Tourism Office, TNK, Inns, Home Stay, Regional Libraries. The problems in this study were analyzed descriptively qualitatively, IFAS analysis (Internal Factors Analysis Summary) and EFAS (External Factors Analysis Summary) and SWOT analysis (Strength Weakneses Opportunities Threat) analysis to design development strategies.

From the research results, it was found that the internal conditions in the form of strength factors in each tourism area in Ende Regency were beautiful natural panoramas, unique community cultures, historical relics, unique social life, beautiful forests with fresh air. Internal conditions are in the form of weakness factors, including: lack of facilities and infrastructure to support tourism activities, lack of promotion of tourism potentials in each area, lack of human resources in the tourism sector, lack of air, sea and air transportation accessibility and the road to tourism potentials is still narrow, there is a lack of local community involvement in tourism activities in their place. The results of the IFAS matrix analysis found that the internal condition of tourism potential in Ende district was in a moderate position, with a total score of 2.33. External conditions in the form of opportunity factors in each area include: The existence of the mission of Ende district 2014-2019, the proximity of tourism potential in areas other than Kelimutu to the tourist attraction of Kelimutu National Park, strategic location and in the middle route of Ende Regency and Flores Island, advances in information technology and transportation, a trend towards world tourism towards natural tourism (Back to Nature), the growth of the global economy. External conditions in the form of threat factors are the threat of global warming, the circulation of drugs, HIV, the threat of population growth due to migrants resulting in land conversion, cultural change (commodification) and environmental pollution in the form of garbage. The results of the EFAS matrix analysis show the position of the external environment. The tourism potential of Ende Regency as a tourist attraction is in a moderate position, with a total score of 2.44 .

The general strategy used in developing tourism potential in each area is a strategy of maintaining and maintaining. This position states that the tourism potential in each tourism 
area has an average moderate and competitive attractiveness position. Alternative strategies for developing tourism potential, including: tourism product development strategies in each region, infrastructure and facilities development strategies, tourism product marketing strategies, institutional development strategies and human resource enhancement in tourism, and sustainable tourism development strategies.

Keywords: potential, tourism development strategy, Ende district

\section{Pendahuluan}

Undang-Undang Nomor 32 Tahun 2004, tentang Otonomi Daerah yang kemudian direvisi dengan Undang-Undang Nomor 34 tahun 2014 tentang Pemerintahan Daerah membawa status perubahan paradigma sistem penyelengaraan pemerintahan pada wilayah pemerintahan yang sentralistik menjadi desentralistik. Daerah semakin diberi peran dan kewenangan yang lebih besar untuk mengatur daerahnya sendiri dengan memanfaatkan berbagai potensi sumber daya yang ada, dalam konstelasi negara Kesatuan Republik Indonesiat. Salah satunya adalah pariwisata.

Alasan utama pengembangann pariwisata pada suatau daerah baik secara lokal, regional, atau ruang lingkup nasional pada suatu nagara sangat erat kaitannya dengan pembangunan perekonomian daerah. Dengan kata lain pengembangan kepariwisataan pada suatu daerah selau akan diperhitungkan dengan keuntungan dan manfaat bagi rakyat banyak.

Sesuai dengan UU Kepariwisataan Nomor 10 Tahn 2010 tujuan pengembangan kepariwisataan adalah:

a. Meningkatkan pertumbuhan ekonomi;

b. Meningkatkan kesejahteraan rakyat;

c. Menghapus kemiskinan;

d. Mengatasi pengangguran;

e. Melestarikan alam, lingkungan, dan sumber daya;

f. Memajukan kebudayaan;

g. Mengangkat citra bangsa;

h. Memupuk rasa cinta tanah air;

i. Memperkukuh jati diri dan kesatuan bangsa; dan

j. Mempererat persahabatan antarbangsa.

Pariwisata merupakan salah satu industri yang kurang mendapat perhatian di wilayah Nusa Tenggara Timur (NTT) pada umumnya, dan Kabupaten Ende khususnya, sedangkan di satu sisi, industri pariwisata adalah kegiatan ekonomi yang dapat menjadi leading sektor Analisis Vol. 20 Tahun II Edisi September 2020 
yang pemicu bagi sektor ekonomi lainnya. Hal ini ditunjukan oleh kurangnya pemanfaatan potensi pariwisata daerah sebagai daya tarik walaupun jumlah kunjungan wisatawan meningkat secara kuantitas. Pemerintah merupakan salah satu stakeholders pembangunan pariwisata memiliki peran yang strategik untuk menentukan arah dan sasaran pembangunan pariwisata, nampaknya belum siap dalam perencanaan, implementasi dan pengelolaan pariwisata yang telah diserahkan oleh pemerintah pusat kepada pemerintah daerah. Implikasinya keberhasilan pembangunan kepariwisataan nasional pada akhirnya sangat tergantung pada kemampuan pemerintah di daerah untuk mengelola sumberdaya pariwisata.

Dirasakan betapa terbatasnya kemampuan birokrasi pariwisata daerah di dalam menjalankan peran strategisnya tersebut, baik dalam perencanaan, implementasi maupun manajemen pembangunan pariwisata. Hal ini tidak saja disebabkan oleh kurangnya koordinasi antara birokrasi pariwisata dengan birokrasi terkait lainnya, melainkan juga oleh realitas sistem rekrutmen dan promosi di lingkungan birokrasi pariwisata yang terlalu didasarkan pada persyaratan umum dan lebih menekankan aspek administrasi-formal. Standar kompetensi yang imperatif bagi birokrasi kepariwisataan untuk dapat menjalankan peran dan fungsi sebagai pengambil keputusan di bidang terkait, yang seyogyanya menjadi kunci keberhasilan pembangunan pariwisata daerah (bandingkan Hendarti, 2001), sampai sekarang belum menjadi kriteria pemilihan pegawai dan staf di lingkungan birokrasi pariwisata.

Adapun kebijakan pokok yang dirumuskan dalam RPJMD merupakan gambaran program pembangunan daerah, karena berisikan prioritas utama implementasi janji politik Bupati dan Wakil Bupati Ende. Program pembangunan Kabupaten Ende Tahun 2014-2019 dikenal dengan "TIWU TELU" atau Tri Warna program pembangunan. Implementasi program pembangunan ini, dilaksanakan melalui strategi pokok pembangun Kabupaten Ende, yang dikenal dengan "Model Segitiga Membangun Kabupaten Ende", yaitu segitiga Pendekatan, Segitiga Kemitraan (Tri Parted) dan Segitiga Kekuatan Bekerja (Lika Mboko Telu) atau Tiga Batu Tungku, dengan spirit utama membangun dari Desa dan Kelurahan berdasarkan karakteristik wilayah.Secara umum Potensi pengembangan untuk RPJM 20142019 didominasi oleh potensi-potensi pariwisata.

Dengan adanya misi tersebut, PemerintahKabupaten Ende dapat menggali dan mengembangkan berbagai potensi yang dimiliki pada sektor kepariwisataan, yaitu wisata alam yang meliputi; Panorama Sunset di Pantai Ria Ende, Gunung Meja, Air Terjun Km 12, 
Air Panas Kolorongo, Gunung Lepembusu, Air Panas Ae Wau, Danau Tiwu Sora, Tanjung Watu Manu, dan Pantai Ippi, Pantai ana bara.

Potensi wisata budaya yang unik yang tersebar di seluruh kecamatan antara lain; Rumah Adat atau Kampung Adat (Koanara, Lise Detu, Wiwi Pemo, Nggela, Tenda, Detusoko, Wolotopo). Tarian tradisional: Gawi, Woge, Wandapala, Wandapau, Simosou, Anajara, dan Mure). Wisata Sejarah; Museum Bung Karno, Benteng Baranuri, Benteng Portugis, Benteng Marilonga, Meriam Kuno, Kuburan Tradisional/kuno, Mumi, dan Watu Gamba. Wisata Religi: Masjid Raya, Gereja Katedral, Gua Maria, dan Patung Kristus Raja. semua daya tarik wisata tersebut tersebar di seluruh wilayah kecamatan di Kabupaten Ende yang sangat potensial dan dapat dikembangkan guna meningkatkan Pendapatan Asli Daerah (PAD). Namun sebagian besar potensi daya tarik wisata tersebut belum di kembangkan secara optimal.

Salah satu potensi daya tarik wisata yang menjadi primadona Kabupaten Ende adalah Danau Tiga Warna Kelimutu yang telah ditetapkan sebagai Kawasan Konservasi Alam Nasional seluas 5.356,50 Ha dan disebut sebagai Taman Nasional Kelimutu.

Dilihat dari segi kuantitas kedatangan wisatawan ke berbagai negara atau daerah tujuan wisata, negara-negara yang menjadi sumber wisatawan, jumlah wisatawan yang melakukan perjalanan, pola perjalanan, data dari Taman Nasional Kelimutu (TNK) Kabupaten Ende selama 7 tahun terakhir hingga akhir tahun 2019 yang lalu mengindikasikan adanya pergeseran yang signifikan dalam hal jumlah dan negara asal wisatawan yang berkunjung ke Danau Kelimutu. Perubahan-perubahan ini tidak terlepas dari dinamika yang terjadi, baik dilihat dari sisi permintaan (demand side) maupun dari sisi pasokan (supply side) produkproduk wisata dari berbagai negara atau daerah tujuan wisata. Kunjungan Wisata ke Danau Kelimutu sebagaidasar patokkanjumlahkunjungan wisata di Kabupaten Ende karena tujuan utaa kunjungan wisatawan adalah Danau Tiga Warnah Kelimutu. Berikut tabel jumlah kunjungan wisata ke Danau Kelimutu Ende selama tuju tahun terakhit dapat di lihat pada tabel 1.1 
Tabel 1.1

Kunjungan Wisata ke Danau Kelimutu Kabupaten Ende, Tahun 2013-2019

\begin{tabular}{|l|l|l|l|}
\hline \multirow{2}{*}{ THN } & \multicolumn{2}{|l|}{ JUMLAH KUNJUNGAN } & \multirow{2}{*}{ TOTAL } \\
\cline { 2 - 3 } & WISNU & WISMAN & \\
\hline 2013 & 26.396 & 8.150 & 34.546 \\
\hline 2014 & 54.701 & 13.184 & 67.885 \\
\hline 2015 & 62.957 & 12.633 & 75.950 \\
\hline 2016 & 81.322 & 14.504 & 95.826 \\
\hline 2017 & 91.219 & 17.802 & 109.021 \\
\hline 2018 & 73.000 & 17.000 & 91.219 \\
\hline 2019 & 71.184 & 15.255 & 86.349 \\
\hline
\end{tabular}

Sumber: Taman Nasional Kelimutu . Ende

Melihat berbagai potensi keunggulan komparatif yang dimiliki Kabupaten Ende umumnya, maka perlu dicarikan solusi alternatif bagi perencanaan daerah Ende, agar keunggulan potensi daerah tersebut dapat diakomodir untuk meningkatkan PAD serta dapat mensejahterakan masyarakat Daerah Ende. Oleh karena itu, penelitian ini bertujuan untuk menginventarisasikan potensi serta strategi pengembangan pariwisata sebagai daya tarik wisata, sehingga dapat diambil kebijakan yang dapat digunakan untuk mengembangkan daya tarik ini secara berkelanjutan.

Penelitian ini bertujuan untuk mengkaji potensi dan prospek kepariwisataan di Kabupaten Ende pada umumnya dan mendeskripsikan potensi pariwisata sebagai daya tarik wisata khusunya. Adapun tujuan khusus sebagai berikut:

1. Untuk mengetahui potensi pariwisata yang dimiliki di Kabupaten Ende sebagai daya tarik wisata

2. Untuk merumuskan srategi dan pengembangan potensi pariwisata sebagai daya tarik wisata.

\section{Landasan Teori}

\section{Tinjauan Tentang Perencanaan}

Pariwisata menggunakan konsep perencanaan umum yang sudah terbukti efektif dalam menghadapi Perencanaan proses pengembangan modern, tetapi menyesuaikan diri dengan karakteristik pariwisata tertentu. Pendekatan perencanaan pariwisata mengarah pada aplikasi praktis dalam perumusan kebijakan dan pengembangan pariwisata. Proses perencanaan dasar yang diterangkan sebelumnya menyediakan kerangka perencanaan yang umum dan penekanan ditempatkan pada konsep perencanaan menjadi berkesinambungan, berorientasi 
sistem, menyeluruh, terintegrasi dan lingkungan dengan fokus pada keberhasilan pengembangan yang dapat mendukung keterlibatan masyarakat. Unsur-unsur dalam pendekatan tersebut adalah sebagai berikut (Inskeep, 1991: 28-29):

1. Pendekatan berkesinambungan, inkremantal dan fleksibel. Pendekatan ini didasarkan pada kebijakan dan rencana pemerintah, baik secara nasional maupun regional. Perencanaan pariwisata dilihat sebagai suatu proses berkesinambungan yang perlu dievaluasi bardasarkan pemantauan dan umpan balik dalam rangka pencapaian tujuan dan kebijakan pengembangan pariwisata.

2. Pendekatan sistem. Pariwisata dipandang sebagai suatu sistem yang saling berhubungan, demikian halnya dengan perencanaan dan teknik analisisnya.

3. Pendekatan menyeluruh. Pendekatan ini dikenal juga sebagai pendekatan holistik. Seperti pada pendekatan sistem seluruh aspek yang terkait dalam perencanaan pariwisata mencakup institusi, lingkungan dan implikasi sosial ekonominya dianalisis dan direncanakan secara menyeluruh.

4. Pendekatan yang terintegrasi. Suatu pendekatan yang dihubungkan dengan sistem dan pendekatan menyeluruh. Pariwisata direncanakan dan dikembangkan sebagai suatu sistem terintegrasi dalam dirinya dan juga terintegrasi dalam keseluruhan rencana dan pola teladan pengembangan daerah.

5. Pendekatan pengembangan berkelanjutan dan lingkungan. Pariwisata direncanakan, dikembangkan, dan diatur berdasarkan sumberdaya budaya dan alami dengan tidak menghabiskan atau menurunkan kualitasnya, tetapi merawat sumberdaya secara permanen untuk pengguna masa depan berkelanjutan. Analisis daya dukung adalah suatu teknik penting menggunakan pendekatan pengembangan berkelanjutan dan lingkungan.

6. Pendekatan masyarakat. Keterlibatan maksimum masyarakat lokal di dalam perencanaan dan proses pengambilan keputusan pariwisata serta keikutsertaan masyarakat maksimum dalam pengembangan manajemen pariwisata dan manfaat sosial ekonominya.

7. Pendekatan pelaksanaan. Kebijakan pengembangan pariwisata, rencana dan rekomendasi dirumuskan untuk dapat dilaksanakan dan realistis, serta teknik implementasi dipertimbangkan sepanjang seluruh kebijakan dan perumusan rencana dengan teknik implementasi, mencakup suatu pengembangan dan program tindakan atau strategi, secara rinci diadopsi dan diketahui. 
8. Aplikasi proses perencanaan sistematis. Proses perencanaan yang sistematis diterapkan dalam perencanaan pariwisata berdasar pada suatu urutan aktivitas logis.

\section{Tinjauan tentang Strategi}

Strategi adalah tujuan jangka panjang dari suatu perusahaan, serta pendayagunaan dan alokasi semua sumber daya yang penting untuk mencapai tujuan perusahaan (Rangkuti. 2003:3). David (2002:4) menyatakan strategi adalah serangkaian keputusan dan tindakan manajerial yang menentukan kinerja perusahaan dalam jangka panjang. Strategi ini meliputi pengamatan lingkungan, perumusan strategi, implementasi strategi dan evaluasi serta pengendalian dan menekankan pada pengamatan peluang, ancaman, kekuatan dan kelemahan perusahaan. Menurut Pearce and Robinson (1997:20) strategi adalah sekumpulan keputusan dan tindakan yang menghasilkan perumusan (formula) dan pelaksanaan (implementasi) rencana-rencana yang dirancang untuk mencapai sasaran perusahaan. Pengertian lainnya dikemukakan oleh Andrews dalam Rangkuti (1997:18-19) yang menyatakan strategi merupakan kekuatan motivasi untuk stakeholders, seperti debtholders, manajer, karyawan, konsumen, komunitas pemerintah dan sebagainya, baik secara langsung maupun tidak langsung menerima keuntungan atau biaya yang ditimbulkan oleh semua tindakan yang dilakukan.

Dari beberapa tinjauan sebelumnya, dapat ditarik sebuah pengertian tentang strategi yang akan dipakai dalam penelitian ini, yaitu tujuan jangka panjang untuk menciptakan keunggulan bersaing sehingga dapat memenuhi apa yang menjadi tujuan yang telah ditetapkan dalam bentuk program-program yang terpadu dan menyeluruh.

\section{Tinjauan Tentang Pengembangan}

Menurut Alwi, dkk (2007: 538) pengembangan adalah proses, cara, perbuatan mengembangkan. Ditambahkan oleh Poewadarminta (2002: 474) pengembangan adalah suatu proses atau cara menjadikan sesuatu menjadi maju, baik, sempurna, dan berguna. Tahapan pengembangan merupakan tahapan siklus evolusi yang terjadi dalam pembangunan pariwisata, sejak suatu daerah tujuan wisata baru ditemukan (discovery), kemudian berkembang dan pada akhirnya terjadi penurunan (decline).

Menurut Kanom dalam penelitiannya (2015), strategi pengembangan Wsata adalah, suatu kesatuan rencana yang sifatnya kompeehensif dan terpadu dari unsur pemerintah, swasta, masyarakat, dan akademisi untuk mengkaji kendala, kondisi lingkungan internal dan 
eksternal objek wisata, sehingga dapat menjadi destinasi pariwisata berkelanjutan serta berdaya saing tinggi.

\section{Tinjauan Tentang Daya Tarik Wisata}

Inskeep (1991: 77) menggunakan kata tourist attraction untuk istilah daya tarik wisata. Inskeep mengklasifikasikan tourist attraction menjadi tiga bagian yaitu:

1. Atraksi alamia yaitu yang berbasiskan lingkungan alamiah.

Kategori utama atraksi alamiah tersebut mencakup: iklim, pemandangan yang indah, laut dan pantai, flora dan fauna, pemandangan alam yang spesial, area konservasi dan taman, serta pariwisata kesehatan yang ada kaitannya dengan lingkungan alamiah.

2. Atraksi budaya yaitu yang berbasiskan aktivitas manusia.

Tipe atraksi budaya adalah meliputi segala sesuatu yang didasarkan pada hasil aktivitas manusia seperti situs budaya, sejarah, dan arkeologi, bentuk-bentuk budaya yang sangat jarang, seni dan kerajinan tangan, aktifitas ekonomi yang menarik, area perkotaan yang menarik, museum dan fasilitas budaya, festifal budaya, serta keramah-tamahan penduduk setempat.

3. Atraksi jenis khusus yaitu hasil ciptaan yang bersifat artifisial.

Atraksi jenis khusus tidak berkaitan dengan wujud-wujud yang alamiah atau tidak berkaitan dengan atraksi budaya namun barkaitan dengan bentuk-bentuk yang diciptakan seperti taman bermain dan hiburan, sirkus, tempat perbelanjaan, MICE, event khusus, kasino, hiburan (entertainment), serta olahraga dan rekreasi.

\section{Tinjauan Tentang Potensi Wisata}

Potensi menurut Alwi, dkk (2007: 890) adalah kemampuan yang mempunyai kemungkinan untuk dikembangkan: kesanggupan; kekuatan; daya. Pendit (1999: 21) menerangkan bahwa potensi wisata adalah berbagai sumber daya yang terdapat disebuah daerah tertentu yang bisa dikembangkan menjadi atraksi wisata. Dengan kata lain, potensi wisata adalah berbagai sumber daya yang dimiliki oleh suatu tempat dan dapat dikembangkan menjadi suatu atraksi wisata (tourist atraction) yang dimanfaatkan untuk kepentingan ekonomi dengan tetap memperhatikan aspek-aspek lainya.

Potensi wisata yang akan dibahas dalam penelitian ini adalah segala potensi pariwisata yang terdapat di Kabupaten Ende yang dapat dikembangkan menjadi daya tarik wisata. 


\section{Metodologi Penelitian}

Penelitian ini merupakan penelitian deskriptif kualitatif dan kuantitatif. Penelitian kualitatif mengidentifikasi faktor-faktor internal dan ekternal potensi pariwisat Kabupaten Ende. Penelitian kuantitatif adalah hasil evaluasi faktor strategis dari faktor internal dan eksternal, penentuan alternatif strategi dan pemilihan alternatif strategi.

Pendekatan yang digunakan dalam mengkaji pengembangan potensi pariwisata Kabupaten Ende adalah merupakan bentuk penelitian yang mendalam tentang suatu aspek lingkungan alam dan lingkungan sosial budaya termasuk stakeholders di dalamnya. Penelitian ini dilakukan di kabupaten Ende. Pengumpulan data pada penelitian ini dilaksanakan dengan menggunakan teknik: 1))Wawancara langsung dengan responden dengan mendatangi responden berdasarkan kuisioner (daftar pertanyaan) yang telah di persiapkan sebelumnya. 2) Observasi, yaitu suatu pengumpulan data dengan pengamatan langsung di lapangan untuk menguji dan melengkapi data lainnya. 3) Dokumentasi yaitu memperoleh data dan informasi yang telah tercatat pada berbagai dokumen tentang berbagai hal yang diperlukan dalam penelitian yang dapat di peroleh pada instansi-instansi terkait, seperti Dinas Pariwisata, TNK, Losmen, Home Stay, Perpustakaan Daerah

\section{Analisis Data}

Analisis data merupakan upaya pemecahan permasalahan penelitian untuk memperoleh jawaban atas permasalahan yang diteliti. Permasalahan dalam penelitian ini akan dianalisis secara deskriptif kualitatif, analisis IFAS (Internal Factors Analysis Summary) dan EFAS (External Factors Analysis Summary) serta analisis SWOT (Strength Weakneses Opportunities Threat) untuk merancang trategi pengembangannya. Dengan ke tiga alat analisis tersebut diharapkan akan dapat memecahkan permasalahan yang akan diteliti. Variabel yang diukur dalam penelitian ini meliputi: potensi wisata, kondisi internal dan eksternal Pariwisata kabupaten Ende, 


\section{Potensi}

Potensi adalah segala sesuatu keunikan yang terdapat di kabupaten Ende dan sekitarnya baik fisik maupun non fisik yang dapat dikembangkan menjadi daya tarik wisata. Potesipotensi tersebut antara lain:

a. Potensi fisik, yaitu berupa bangunan-bangunan rumah tradisional, keadaan lingkungan, serta potensi fisik lainnya yang mendukung pengembangan Kawassan kelimutu Ende dan sekitarnya pariwisata di Kab upaten Ende.

b. Potensi non fisik, yaitu potensi berupa kegiatan masyarakat lokal yang erat hubungannya dengan kegiatan-kegiatan wisatawan, seperti pola hidup dan kerja, organisasi masyarakat lokal (lembaga adat setempat) dan kearifan masyarakat lokal

\section{Faktor Internal dan Faktor Eksternal}

a. Faktor Internal

Faktor internal yang dimaksud adalah faktor-faktor yang menjadi kekuatan dan kelemahan potensi pariwisata. Faktor-faktor kekuatan dan kelemahan tersebut berupa faktor lingkungan yang berupa produk-produk seperti keindahan dan keunikan alam, aksesibilitas, fasilitas pariwisata, sumber daya manusia, dan faktor sosial budaya masyarakat di kabupaten Ende.

b. Faktor eksternal

Faktor ekternal yang dimaksud adalah faktor-faktor yang menjadi peluang dan ancaman potensi pariwisata kabupaten Ende. Faktor-faktor tersebut adalah faktor ekonomi, faktor politik dan keamanan.

\section{Strategi Pengembangan}

Strategi pengembangan yang dimaksud dalam penelitian ini adalah rencana sistematis untuk mengembangkan potensi pariwisata, yang dalam pengembangannya melihat pada kekuatan, kelemahan, peluang dan ancaman yang ada di kabupaten Ende.

\section{Hasil dan Pembahasan}

\section{Potensi Wisata di Kabupaten Ende}

Potensi wisata dapat diartikan sebagai segala sesuatu yang terdapat di Kabupaten Ende baik potensi fisik maupun non fisik yang dapat dikembangkan menjadi daya tarik wisata. Potensi wisata tersebut berhubungan dengan alam, sosial budaya dan juga masyarakat 
lokal. Potensi wisata yang terdapat di Kabupaten Ende berdasarkan pengertian tersebut antara lain:

a. Potensi fisik, yaitu berupa bangunan-bangunan rumah tradisional, keadaan lingkungan, serta potensi fisik lainnya yang mendukung pengembangan Kawassan Kelimutu Ende dan sekitarnya pariwisata di Kabupaten Ende.

b. Potensi non fisik, yaitu potensi berupa kegiatan masyarakat lokal yang erat hubungannya dengan kegiatan-kegiatan wisatawan, seperti pola hidup dan kerja, organisasi masyarakat lokal (lembaga adat setempat) dan kearifan masyarakat lokal.

Potensi pariwisata di kabupaten Ende berdasarkan kawasan yakni:

1. Kawasan Strategis Pariwisata Nasional (KSPN) Ende- Kelimutu dan sekitarnya

a) Klaster I Kecamatan Kelimutu: danau Kelimutu, air terjun, sumber air panas, dan gas alam, kampung adat, musik tradisional, seremoni adat, pasar tradisional, wisata agro, kulinerlokal, tracking, kolampemancinganikan, proses pembuatan tenun ikat secara tradisional.

b) Klaster II Kecamatan Wolowaru: air Terjun, Sumber Air Panas, Kampung adat, seremoni adat,pasar tradisional, wisata agro, kuliner lokal, proses pembuatan tenun ikat secara tradisonal, kerajinan Souvenir, trekking, wisata ziara.

c) Klaster III, kecamatan Wolojita: simber Air Panas, seremoni adat, pasar tradisional, kuliner lokal, proses pembuatan tenun ikat secara tradisional

d) Klaster IV Kecamatan Ndona Timur: Gas alam, kampung adat, seremoni adat, kerajinan anyaman tadisional, wisata agro.

e) Klaster V, Kecamatan Detusoko: air terjun, Sumber air panas, kampung adat, seremoni adat, Wisata rohani, camping ground, sawah bertingkat, kerajinan pandai besi, mumi, Belut Sakti,

f) Klaser VI, Kecamatan Ndona: Pantai Mbu;u, Kampung adat Rada Ara, Kampung adat Wolotopo, proses pembuatan tenun ikat secara tradisional, dll

g) Klaster VII, Kecamatan Ende Timur: Air terjun, Sungai, kampung adat, pantai, dll

h) Klaster VIII, Kecamatan Ende Tengah: Gunung, kampung adat, wisata kota, dll

i) Klaster IX, Kecamatan Ende Utara, pantai, sunset, kampungadat, Naskah Lota,SitusBung Karno, taman Pancasila,dll

j) Klaster X, Kecamatan Ende Selatan: Pantai, Gunung, sunset, pasar tradisional 
2. Kawasan Pariwisata Maurole - Detukeli - Wewaria

A. Klaster I, Kecamatan Maurole: pantai, teluk, rekreasi pantai, sunset dan sunrise, pertunjukansenibudaya, kampung adat, seremoni adat, pasar tradisional, pembuatan gula aren secara tradisional,pembuatantuak (moke), kuliner lokal, wisata perdesaan, tracking.

B. Klaster II, Kecamatan Detukeli: semburan panas bumi, kampung adat, seremoni adat, situs BentengMarilonga, kulinerlokal

C. Klaster III, kecamatan Wewaria: Panorama Landscape, kampung adat, pasar tradisional, permainantradisonal, kulinerlokal.

3. Kawasan Pariwisata KotaBaru - LepembususKelisoke

A. Klaster I, Kecamatan Kota Baru: pantai, danau, hutan hujan Tropis, fauna, semburan Air panas, Panorama Padang, kampungadat, tracking, wisata agro, wisata tirta.

B. Klaster II, Kecamatan Lepembusu: panorama Alam Padang, gunung Lepembusu, kampungadat, tracking, wisata agro.

4. KawasanPariwisata Lio Timur-Ndori: sumber Air panas, gua Kelelawar, batualam, panorama landscape, kampung adat, warisan lota, mumi, pasar tradisional, kerajinananyamantikar, pantai, sungai, kawasaniniterdiridariduaKlasteryakni: Klaster I Kecamatan Lio Timur dan klaster II KecamatanNdori.

5. KawasanPariwisata Ende - Nangapada - pulau Ende - Maukaro: pantai, batu hijau, batu alam, air panas, air terjun, gua, danau, pulau karang, kampungadat, pasar tradisional, peninggalansejarah, wisata agro, tracking.

Kawasan ini terdiridari 3 (tiga) klasteryakni: Klaster I, Kecamatan Ende, klaster II, kecamatan Nangapanda, dan Klaster III kecamatan pulau Ende sumber (RIPPADA Ende 2015)

Sejumlah potensi wisata yang tersebar di setiap kecamatan pada masing-masing kawasan pariwisata tersebut sebagiannya sudah di kelolah oleh pemerintah (dinas pariwisata) sedangkan sebagiannya belum dan bahkan belum diketahui oleh publik dan sifatnya masih sporadis. Potensi pariwisata yang dikelolah oleh pemerintah antara lain Air panas Detusoko, pantai Ende (pantai Ria), pantai Mbu'u, tanjung Watu Manu, Pantai Ana Bara Maurole, kawasan Moni Koa Nara, Pantai Nggemo, Pantai Mbuli Waralau - Wolowaru, Desa-Desa wisata, kampung tradisional, Situs Bung Karno, Semua potensi tersebut belum dikelolah secara baik, sehingga jumlah kunjungannyapun sangat minim. 


\section{Analisis Lingkungan Internal Potensi Pariwisata di Kabupaten Ende}

\section{Hasil Analisis Terhadap Faktor-faktor Internal Dengan Menggunakan Matriks IFAS (Internal Factors Analysis Summary}

\begin{tabular}{|c|c|c|c|}
\hline KEKUATAN & Bobot & Rating & $\begin{array}{l}\text { Skor ( bobot } \mathrm{x} \\
\text { rating) }\end{array}$ \\
\hline A.Panorama Alam yang indah & 0.168 & 4 & 0.672 \\
\hline B. Budaya masyarakat yang unik & 0.091 & 3.733 & 0.339703 \\
\hline C. Peninggalan sejarah & 0.063 & 3.066 & 0.193158 \\
\hline D. Kehidupan social masyarakat yang unik & 0.069 & 3.133 & 0.216177 \\
\hline E.Hutan yang asri dan udara segar & 0.061 & 3 & 0.183 \\
\hline \multicolumn{4}{|l|}{ KELEMAHAN } \\
\hline $\begin{array}{l}\text { A. Kurangtersedianyaprasaranadan sarana penunjang aktivitas } \\
\text { pariwisata, seperti belum adanya tempat makan, penginapan, } \\
\text { parkiran dan pusat informasi pariwisata pada masing-masing } \\
\text { kawasan wisata }\end{array}$ & 0.131 & 1 & 0.131 \\
\hline $\begin{array}{l}\text { B.Kurangnyapromosimengenaikeberadaanpotensi-potensiwisata } \\
\text { di kabupaten Ende }\end{array}$ & 0.128 & 1.133 & 0.145024 \\
\hline $\begin{array}{l}\text { C.Kurangtersedianya SDM yang memiliki pengetahuan dan } \\
\text { ketrampilan dalam bidang pariwisata }\end{array}$ & 0.12 & 1.195 & 0.1434 \\
\hline D. Kurang tersedianya trnsportasi laut dan udara. & 0.067 & 2.733 & 0.183111 \\
\hline $\begin{array}{l}\text { E. Kurangnya keterlibatan masyarakat lokal dalam kegiatan } \\
\text { pariwisata. }\end{array}$ & 0.102 & 1.266 & 0.129132 \\
\hline TOTAL & 1 & & 2.335705 \\
\hline
\end{tabular}

Sumber: Data : Hasil Analisis 2019

Dari tabel diatas menunjukan bahwa pemeringkatan faktor-faktor internal yang terdiri dari faktor-faktor kekuatan dan kelemahan mengahasilkan peringkat (rating) yang berbedabeda. Faktor kekuatan yang memperoleh tingkat pengaruh tertinggi, yaitu dengan nilai rating 4.000 adalah faktor Panorama alam yang indah. Budaya masyarakat yang unik menduduki peringkat kedua atau tingkat pengaruh kedua dengan rating 3.733.

Tingkat pengaruh terpenting ketiga dengan rating 3.133 adalah kehidupan sosial masyarakat yang unik. Peninggalan sejarah merupakan peringkat ke empat dengan rating 3.066 dan hutan yang masih asri dengan udara yang segar, serta dihuni oleh beberapa jenis burung Nuri Hijau (trichoglossus haematodus), Kelelawar (Chiropterasp), Gagak Hitam, Koka. merupakan faktor pengaruh terpenting ke lima atau terakhir dengan rating 3.

Pembobotan faktor-faktor internal berupa kelemahan memperoleh bobot yang berbedabeda. Faktor kelemahan terpenting pertama adalah kurang tersedianya prasarana dan sarana 
penunjang aktivitas pariwisata. dengan bobot 0.138 . semua potensi pariwisata yang tersebar pada msing-masing kawasan kecuali Danau Kelimutu, belum memiliki sarana penunjang pariwisata syang memadai Sehingga Wisatawan cendrung membawa makananan dan minuman sendiri dari tempat asalnya.

Kurangnya promosi mengenai keberadaan potensi-potensi pariwisata di Kabupaten Ende merupakan faktor kelemahan terpenting kedua dengann bobot 0.128 . kurang lebih $80 \%$ wisatawan belum mengetahui akan keberadaan potensi-potensi wisata yang terdata oleh Dinas Pariwisata, dan wisatawanpun mengetahui Danau Kelimutu dari teman atau keluarga yang pernah mengunjungi danau tersebut.

Kurang tersdianya SDM yang memiliki pengetahuan dan ketrampilan dalam bidang pariwisata menduduki kelemahan terpenting ke tiga dengan bobot 0.120.

Faktor kelemahan terpenting ke empat, dengan bobot 0.102 adalah kurangnya keterlibatan masyarakat lokal dalam kegiatan pariwisata. Masyarakat yang sebenarnya sebagai pemilik suatau daya tarik karena terletak di wilayah mereka mempunyai kecenderungan menjadi orang asing dalam kegiatan kepariwisataan di wilayahnya. Faktor kelemahan terpenting terakhir adalah jalan menuju beberapa potensi wisata pada masingmasing kawasan pariwisata di kabupaten Ende belum ada dan masih sangat sempit. Bobot dari faktor kelemahan terpenting ke lima ini adalah 0.067 Akses transportasi udara dan laut di Kabupaten Ende sangat terbatas, hal ini dibuktikan dengan wisatawan yang berkunjung ke kawasan ini hanyalah wisatawan lokal dan nusantara.

Pemeringkatan terhadap faktor-faktor kelemahan memperoleh peringkat (rating) yang berbeda-beda. Faktor kelemahan yang memperoleh peringkat atau tingkat pengaruh paling kuat pertama dengan rating 1 adalah kurang tersedianya prasarana dan sarana penunjang aktivitas pariwisata, Kurangnya promosi menganai keberadaan potensi-potensi pariwisata di Kabupaten Ende merupakan faktor kelemhan terpenting kedua denganrating 1.133. Faktor kelemahan terpenting ke tiga gengann rating 1.195 adalah Kurang tersedianya SDM yang memiliki pengetahuan dan keterampilan dalam bidang pariwisata

Faktor kelemahan terpenting ke empat, dengan rating 1.266 adalah kurangnya keterlibatan masyarakat lokal dalam kegiatan pariwisata. Sebagai faktor ancaman terpenting terahir atau kelima adalah akses transportasi udara, lautdan darat dengan rating 2.733 


\section{Analisis Kondisi Lingkungan Eksternal Potensi Pariwisata Kabupaten Ende}

\section{Hasil Analisis Terhadap Faktor-faktor Eksternal Dengan Menggunakan Matriks EFAS} (Ekternal Factors Analysis Summary)

\begin{tabular}{|c|c|c|c|}
\hline INDIKATOR PELUANG & Bobot & Rating & Skor (bobot X Rating) \\
\hline 1 & 2 & 3 & 4 \\
\hline $\begin{array}{l}\text { Adanya misi kabupaten Ende 2014- } \\
2019\end{array}$ & 0.076 & 2.93 & 0.22268 \\
\hline $\begin{array}{l}\text { Dekatnya jarak kawasan tersebut } \\
\text { dengan daya tarik Taman nasional } \\
\text { Kelimutu }\end{array}$ & 0.108 & 3.66 & 0.39528 \\
\hline $\begin{array}{l}\text { Letaknya sangat Strategis, karena } \\
\text { berada di jalur tengah Pulau Flores }\end{array}$ & 0.088 & 3.73 & 0.32824 \\
\hline $\begin{array}{l}\text { Kemajuanteknologiberupateknologi } \\
\text { informasi dan transportasi }\end{array}$ & 0.06 & 3.53 & 0.2118 \\
\hline $\begin{array}{l}\text { Adanya kecenderungan pariwisata } \\
\text { Dunia menuju pariwisata yang Alamia } \\
\text { (Back to Nature) }\end{array}$ & 0.084 & 3.33 & 0.27972 \\
\hline TumbuhnyaEkonomi Global & 0.064 & 3.26 & 0.20864 \\
\hline \multicolumn{4}{|l|}{ ANCAMAN } \\
\hline Ancaman Global Warming & 0.07 & 2.2 & 0.154 \\
\hline Beredarnya Narkoba, HIV & 0.068 & 1.533 & 0.104244 \\
\hline $\begin{array}{l}\text { Situasi keamanan dan politik nasional } \\
\text { yang tidak stabil }\end{array}$ & 0.09 & 1.666 & 0.14994 \\
\hline $\begin{array}{l}\text { Ancaman pertambahan penduduk akibat } \\
\text { migran (kapasitas daya tampung) }\end{array}$ & 0.104 & 1.4 & 0.1064 \\
\hline Perubahan Budaya (komodifikasi) & 0.114 & 1.133 & 0.129162 \\
\hline Pencemaran lingkungan berupa sampah & 0.078 & 1.866 & 0.145548 \\
\hline TOTAL & 1.004 & 30.238 & 2.435654 \\
\hline
\end{tabular}

Sumber: Data : Hasil Analisis 2019

Dari Tabel diatas diperoleh bahwa faktor-faktor peluang dan faktor-faktor ancaman memperoleh bobot yang berbeda-beda. Faktor peluang yang terpenting pertama dengan bobot 0.108 adalah dekatnya jarak kawasan potensi pariwisata dengan daya tarik wisata Taman Nasional Kelimutu. Faktor peluang terpenting ke dua dengan bobot 0.088 adalah letaknya strategis dan berada pada jalur tengah Pulau Flores. Keberadaan Kawasan - kawasan potensi pariwisata di kabupaten Ende pada jalur Tengah Pulau Flores merupakan peluang untuk 
menarik wisatawan dari berbagai daerah untuk mengunjungi daya tarik pada berbagai kawsasan. Kabu;paten Ende yang letak geografisnya sangat startegis dapat dijadikan tempat transit bagi wisatawan baik Nusantara maupun Manca Neggara yang tujuannya wisatanya ke kabupaten lain yang ada di daratan Flores dan Lembata.

Faktor peluang terpenting ke tiga dengan bobot 0.084 adalah adanya kecenderungan pariwisata Dunia menuju pariwisata yang alamia (Back To Natural).

Adanya misi Kabuapten Ende 2014-2019 merupakan faktor peluang ke empat dengan bobot 0.076. Misi merupakan suatu kegiatan atau program yang akan dikerjakan pada saat misi di keluarkan sesuaia dengan periode yang telah dditentukan. Salah satu Misi kabupaten Endh:e adala

1. Percepatan Pembangunan Perekonomian dan Pariwisata yang kompetitif dan berkelanjutan;

2. 2..Membangun, menata, dan meningkatkan sarana dan prasarana penunjang secara kuantitatif maupun kualitatif sesuai potensi dan kebutuhan daerah yang ramah lingkungan

Dengan adanya misi tersebut memberikan rambu-rambu kepada masyarakat baik pemirintah maupun swasta yang memiliki modal untuk berinvestasi di bidang pariwisata guna percepatan pembangunan perekonomian dengan tetap memeperhatikan lingkungan.

Tumbuhnya Ekonomi Global adalah faktor peluang terpenting ke lima dengan bobot 0.064 .

Faktor peluang terpenting ke enam atau terakhir dengan bobot 0.06 adalah kemajuan teknologi informasi dan transportasi.. Pemeringkatan terhadap faktor-faktor peluang memperoleh peringkat (rating) yang berbeda-beda. Faktor peluang yang memperoleh peringkat atau tingkat pengaruh paling kuat pertama dengan rating 3.73 adalah adalah letaknya strategis dan berada pada jalur Tengah Pulau Flores. Dekatnya jarak kawasan potensi pariwiasata dengan daya tarik Taman Nasional Kelimutu merupakan faktor peluang terpenting kedua deangan rating 3.66. faktor peluang dengan tingkat pengaruh paling kuat ke tiga adalah Kemajuan teknologi informasi dan transportasi dengan rating 3.53. Adanya kecenderungan pariwisata Dunia menuju pariwisata yang alamiah (Back To Nature) merupakan faktor peluang terpenting ke empat dengan rating 3.33. . Faktor peluang dengan tingkat pengaruh paling kuat ke lima adalah tumbuhnya ekonomi Global dengan rating 3.26 dan yang tgerakhir dengan rating 2.93 adalah adanya Misi Kabupaten Ende 2014-2019 


\section{Strategi Pengembangan Potensi Pariwisata kabupaten Ende Sebagai Daya Tarik}

\section{Wisata}

Dalam membuat strategi pengembangan potensi pariwisata di kabupaten Ende, diawali dengan menguraikan faktor-faktor internal dan eksternal. Faktor-faktor internal dianalisis dengan mengunakan matriks IFAS dan faktor-faktor eksternal dianalisis dengan menggunakan matriks EFAS. Dari penggabungan hasil kedua matriks (IFAS dan EFAS) diperoleh strategi yang bersifat umum (general strategi). Kemudian dilanjutkan dengan menggunakan matriks SWOT (Strengths Weaknesses Opportunities and Threats) untuk merumuskan strategi alternatifnya.

Gabungan kedua total skor IFAS dan EFAS kedalam diagram matriks InternalEksternal (IE) akan menunjukan posisi potensi pariwisata sebagai daya tarik wisata di dalam diagram sembilan sel matriks IE, seperti pada Tabel berikut:

Matriks Total EFAS-IFAS

\begin{tabular}{|c|c|c|c|}
\hline${ }_{\text {EFE }}^{\text {IFAS }}$ & $\begin{array}{c}\text { KUAT } \\
3,0-4,0\end{array}$ & $\begin{array}{l}\text { SEDANG } \\
2,0-2,99\end{array}$ & $\begin{array}{c}\text { LEMAH } \\
1,0-1,99\end{array}$ \\
\hline $\begin{array}{r}\text { KUAT } \\
\mathbf{3 , 0}-\mathbf{4 , 0} \\
\text { m } \\
\text { b }\end{array}$ & \begin{tabular}{l}
\multicolumn{1}{c}{ I } \\
Tumbuh dan bina \\
(kosentrasi via \\
integrasi vertikal)
\end{tabular} & $\begin{array}{l}\quad \text { II } 2335 \\
\text { Tumbuh dan bina } \\
\text { (kosentrasi via } \\
\text { integrasi } \\
\text { horisontal) }\end{array}$ & $\begin{array}{l}\text { III } \\
\text { Pertahankan pelihara } \\
\text { (pertumbuhan } \\
\text { berputar) }\end{array}$ \\
\hline $\begin{array}{r}\text { SEDANG } \\
2,0-2,99 \\
\mathrm{r} \\
:\end{array}$ & $\begin{array}{l}\text { IV } 2.435 \\
\text { Tumbuh dan bina } \\
\text { (berhenti sejenak) }\end{array}$ & \begin{tabular}{l}
\multicolumn{1}{c}{$\mathrm{V}$} \\
Pertahankan dan \\
pelihara (strategi \\
tidak berubah)
\end{tabular} & $\begin{array}{l}\text { VI } \\
\text { Panen atau difestasi } \\
\text { (daya tarik wisata } \\
\text { terikat atau jual habis } \\
\text { daya tarik wisata) }\end{array}$ \\
\hline \begin{tabular}{r}
\multicolumn{2}{c}{ LEMAH } \\
$\mathbf{1 , 0}-\mathbf{1 , 9 9}$ \\
$H$ \\
$a$
\end{tabular} & \begin{tabular}{l}
\multicolumn{1}{c}{ VII } \\
Pertahankan dan \\
pelihara (difersifikasi \\
kosentrasi)
\end{tabular} & $\begin{array}{l}\text { VIII } \\
\text { Panen atau difestasi } \\
\text { (diversifikasi } \\
\text { konglomerat) }\end{array}$ & $\begin{array}{l}\text { IX } \\
\text { Panen atau difestasi } \\
\text { (likuidasi) }\end{array}$ \\
\hline
\end{tabular}

Dari tabel tersebut memperlihatkan bahwa posisi potensi pariwisata kabupaten Ende berada pada sel V, yang berarti berada pada posisi pertahankan dan pelihara. Posisi ini menyatakan bahwa Kabupaten Ende dengan posisi dalam operasi daya tarik sedang dan memiliki posisi kompetitif rata-rata. 


\section{Strategi yang dilakukan}

1. Strategi SO (Strengths Opportunities)

Strategi SO adalah strategi yang memanfaatkan seluruh kekuatan potensi Pariwisata yang terdapat di Kabupatenn Ende untuk merebut dan memanfaatkan peluang yang dimilikinya. Strategi yang dihasilkan adalah strategi pengembangan produk wisata. Potensi-potensi wisata di Kabupaten Ende merupakan kekuatan yang dapat dijadikan daya tarik wisata yang unggul karena memiliki panorama alam yang indah keunikan budaya dan kekhasan kehidupan sosial masyarakat, peninggalan sejarah dan hutan yang masih asri. Dengan memanfaatkan peluang berupa dekatnya jarak potensi Pariwisata dengan Daya Tarik wisata Taman Nasional Kelimutu, Letaknya sangat strategis karena berada di jalur tengah Pulau Flores, kecenderungan pariwisata dunia yang mengarah pada pariwisata alam (alternatif), pengembangan produk wisata di kawasaninisangatlahmenjanjikan, membuatpotensi-potensipariwisata di Kabupaern Ende dengan produk wisata yang dimilikinya menjadi destinasi wisata yang memiliki peluang sangat baik.

\section{Strategi ST (Strengths and Threats)}

Strategi dalam menggunakan kekuatan yang dimiliki untuk mengatasi ancaman yang dihadapinya. Strategi yang dikembangkan adalah Strategi Pariwisata Berkelanjutan (mempertahankan fungsi lahan dan budaya setempat).

\section{Strategi WO ( Weknesses Opportunities)}

Strategi ini diterapkan berdasarkan pemanfaatan peluang yang ada dengan cara meminimalkan kelemahan. Beberapa hal yang harus dilakukan adalah:

- Strategi pertama adalah Pengembangan sarana prasarana pendukung pariwisata.

- Strategi kedua adalah pemasaran (program promosi) menjadi salah satu upaya untuk memanfatkan semua peluang yang ada dan meminimalkan kelemahan yang dimiliki, Perlu adanya inovasi-inovasi dalam system promosi dengan peningkatan pemanfaatan teknologi informasi dan pemanfaatan letak geografis Kabupaten Ende yang berada pada jalur Tengah Pulau Flores dan dekatnya potensi-potensi pariwisaata pada masing-masing kawasan dengan Taman Nasional Kelimtu untuk mempromosikan potensiwisata yang dimiliki.

- Strategi ketiga adalah pengembangan kelembagaan dan peningkatan sumber daya manusia (SDM).Sstrategi pengembangan kelembagaan dan SDM lokal di bidang 
pariwisata perlu dilakukan. Keterbatasan dan kurangnya fasilitas penunjang obyek wisata, kurangnya kuantitas dan spesialiasasi SDM pada dinas Pariwisata dalam mengelolah potensi pariwisata tersebut diperlukan tenaga-tenaga khusus yang ahli dibidang kepariwisataan..

\section{Strategi WT (Weaknesses Threats)}

Strategi ini didasarkan kepada kegiatan yang bersifat defensif yaitu strategi yang meminimalkan kelemahan dan menghindari ancaman.

- Strategi pertama yang dikembangkan adalah strategi untuk memepertahankan Budaya lokal, tujuan strategi ini adalah; Masyarakat lokal tidak terpengaruh oleh gaya hidup, cara berpakian wisatawan yang datang serta tidak mengkomersialkan kebudayaan berupa upacara adat yang tidak sesuai dengan waktu yang sebenarnya. Budaya yang kuat dapat menghindari ancaman beredarnya narkoba dan penyebaran HIV

- Strategi ke dua yang dikembangkan adalah strategi untuk memepertahankan fungsi lahan sebagai daerah persawahan, perkebunanan dan peternakan..Tujuan satrategi ini adalah untuk menghindari ancaman yang ada seperti, pengalihan fungsi lahan akibat pertambahan jumlah penduduk.

- Strategi ke tiga adalah strategi pengembangan kelembagaan dan peningkatan sumber daya manusia di bidang pariwisata. Tujuan dari starategi ini adalah untuk meningkatkan SDM lokal dalam mengatur mengelola Kawasan pariwisata agar berkelanjutan. Tujuan lainnya adalah adanya peran serta aktif masyarakat lokal dalam bentuk kelembagaan untuk mengelola Kawasan pariwisata sebagai daya tarik wisata..

- Strategi ke empat adalah pengembangan sarana dan prasarana di kawasan ini dengan tetap memperhatikan kelestarian lingkungan berbasis masyarakat. Tujuan strategi ini adalah mengatasi kelemahan yang ada (berupa kurangnya sarana dan prasarana pariwisata, serta keterbatasan transportasi laut dan udara di Kabupaten Ende). 


\section{Kesimpulan}

Potensi- potensi pariwisata yang terdapat pada masing-masing kawasan pariwisata dapat dikembangkan sebagai daya tarik wisata berdasarkan potensi-potensi wisata yang terdapat di kawasan tersebut. Potensi-potensi wisata yang terdapat pada masing-masing kawasan sebagai berikut:

Potensi wisata dapat diartikan sebagai segala sesuatu yang terdapat di Kabupaten Ende baik potensi fisik maupun non fisik yang dapat dikembangkan menjadi daya tarik wisata. Potensi wisata tersebut berhubungan dengan alam, sosial budaya dan juga masyarakat lokal. Potensi wisata yang terdapat di Kabupaten Ende berdasarkan pengertian tersebut antara lain:

a. Potensi fisik, yaitu berupa bangunan-bangunan rumah tradisional, keadaan lingkungan, serta potensi fisik lainnya yang mendukung pengembangan Kawassan Kelimutu Ende dan sekitarnya pariwisata di Kabupaten Ende.

b. Potensi non fisik, yaitu potensi berupa kegiatan masyarakat lokal yang erat hubungannya dengan kegiatan-kegiatan wisatawan, seperti pola hidup dan kerja, organisasi masyarakat lokal (lembaga adat setempat) dan kearifan masyarakat lokal.

Potensi pariwisata di kabupaten Ende berdasarkan kawasan yakni:

1. Kawasan Strategis Pariwisata Nasional (KSPN) Ende- Kelimutu dan sekitarnya.

2. Kawasan Pariwisata Maurole - Detukeli - Wewaria.

3. Kawasan Pariwisata KotaBaru - LepembususKelisoke.

4. Kawasan Pariwisata Lio Timur - Ndori

5.KawasanPariwisata Ende - Nangapada - pulau Ende - Maukaro

Kondisi internal berupa faktor-faktor kekuatan pada masing-masing Kawasan pariwsata di Kabupatenn Ende adalah Panorama alam yang indah, Budaya Masyarakat yang Unik, Peninggalan Sejarah, Kehidupan Sosial Masyarakat yang unik, Hutan yang asri dengan udaranya yang segar. Kondisi internal berupa faktor-faktor kelemahan, diantaranya: kurang tersedianya sarana dan prasarana penunjang aktivitas pariwisata, kurangnya promosi tentang potensi-potensi pariwisata di masing-masing kawasan, kurang teresedianya sumber daya manusia di bidang pariwisata, kurangnya aksesbilitas transportasi udara, laut dan udara serta jalan menuju potensi-potensi wisata masih sempit, kurangnya keterlibatan masyarakat lokal dalam kegiatan pariwisata di temapat mereka. Hasil analisis matriks IFAS didapati bahwa kondisi internal potensi pariwisata di kabupaten Ende berada pada posisi sedang, yaitu 
dengan total skor 2.33. Kondisi eksternal berupa faktor-faktor peluang pada masing-masing Kawasan meliputi: Adanya misi kabupaten Ende 2014-2019, dekatnya jarak potensi wisata pada kawasan selain kelimutu dengan daya tarik wisata Taman Nasional Kelimutu, letaknya strategis dan berada pada jalur Tengah Kabupaten Ende dan Pulau Flores, adanya kemajuan teknologi informasi dan transportasi, adanya kecenderungan pariwisata dunia menuju pariwisata alami (Back to Nature ), Tumbuhnya ekonomi Global. Kondisi eksternal berupa faktor-faktor ancaman adalah ancaman global warming, beredarnya Narkoba, HIV, ancaman pertambahan penduduk akibat migran sehingga terjadi pengalihan fungsi lahan, Perubahan Budaya (komodifikasi) dan Pencemaran lingkungan berupa sampah. Hasil analisis matriks EFAS menunjukan posisi lingkungan eksternal Potensi pariwisata Kabupaten Ende sebagai daya tarik wisata berada pada posisi sedang, yaitu dengan total skor $\mathbf{2 . 4 4}$

Strategi umum yang dipakai dalam mengembangkan potensi wisata pada masingmasing kawasan adalah strategi petahankan dan pelihara. Posisi ini menyatakan bahwa potensi wisata pada masing-masing kawasan pariwisata memiliki posisi daya tarik sedang dan kompetitif rata-rata. Strategi alternatif pengembangan potensi pariwisata, meliputi: strategi pengembangan produk wisata pada masing-masing kawasan, strategi pengembangan sarana dan prasarana, strategi pemasaran produk wisata, strategi pengembangan kelembagaan dan peningkatan SDM di bidang pariwisata, dan strategi pengembangan pariwisata berkelanjutan.

\section{DAFTAR PUSTAKA}

Adhisakti, Laretna.T. 2000. "Strategi Pembangunan Desa di Indonesia". Dalam Makalah Seminar Pemberdayan Pariwisata berbasis Kerakyatan dalam Menyongsong Otonomi daerah Bali.

Alwi, H. Hans, L. Dendy, S. Dameria, N. 2007. Kamus Besar Bahasa Indonesia. Edisi keempat. Jakarta: Balai Pustaka

Amirullah, 2002.Manajemen Srategik, Yogyakarta: Graha Ilmu

Antara, M, 2008. Teknik Analisis Data dan Penerepannya dalam Penelitian: Materi Metodologi Penelitian. Denpasar: S2 Kajian Pariwisata Universitas Udayana

Kusmayadi dan Endar Sugiarto, 2000. Metodologi Penelitian Dalam Bidang Kepariwisataan. Jakarta: PT Gramedia Pustaka Utama. 
ANALISIS POTENSI DAN STRATEGI PENGEMBANGAN PARIWISATA DI KABUPATEN ENDE Yustina Paulina Penu

Paturusi, Syamsul Alam, 2001, Perencanaan Tata Ruang Kawasan Pariwisata, Materi kuliah perencanaan Kawasan Pariwisata Program Magister Pariwisata (S2) Kajian pariwisata, Progran Pasca Sarjana Universitas Udayana Denpasar

Sudana, I Putu Jurnal Pariwisata Vol 13 No.1 Strategi Pengembangna Desa Wisata Ekologis di Desa Belimbing, Kecamatan Pupuan kabupaten Tabanan, Fakultas Pariwisata Universitas Udayana 